\title{
Rheological Properties of Gluten as Function of Sodium Chloride During Heating
}

\author{
Helen C. D. Tuhumury
}

\author{
Department of Agricultural Product Technology, Faculty of Agriculture, Pattimura University \\ Jl. Ir. M. Putuhena Kampus Poka Ambon 97233 \\ *Corresponding Author: E-mail: hcdtuhumury@yahoo.com
}

\begin{abstract}
Both rehydrated and fresh gluten samples were prepared in the presence and absence of $\mathrm{NaCl}$ during mixing and washing. The samples were subjected to the temperature sweep to determine the rheological properties of gluten during heating as a function of $\mathrm{NaCl}$. In addition, the starch was added back to the gluten samples with and without $\mathrm{NaCl}$ to determine the effect of residual starch in the gluten network as influenced by $\mathrm{NaCl}$. Gluten network formed in the presence of $\mathrm{NaCl}$ determine its rheological properties during heating. $\mathrm{NaCl}$ caused the enhanced hydrogen bonding in the formation of the gluten network during hydration, which may cause the onset in the sharp increase in G' at higher temperature during heating. The delay of the sharp increase in the G' value to higher temperature during heating is the results of the formation of the gluten network in the presence of $\mathrm{NaCl}$ not of the presence of the residual starch in the gluten network.
\end{abstract}

Keywords: gluten, salts, small deformation rheology, starch, temperature sweep

\section{ABSTRAK}

Sampel gluten rehidrasi dan gluten yang baru dicuci disiapkan dengan dan tanpa $\mathrm{NaCl}$ selama proses pencampuran dan pencucian. Pengukuran reologi temperature sweep dilakukan untuk menentukan karakteristik reologi gluten selama proses pemanasan sebagai fungsi $\mathrm{NaCl}$. Pati ditambahkan kembali pada gluten untuk proses rehidrasi dengan dan tanpa $\mathrm{NaCl}$ untuk menentukan pengaruh residu pati pada gluten seperti yang dipengaruhi oleh $\mathrm{NaCl}$. Pembentukan jaringan gluten dengan $\mathrm{NaCl}$ selama pencampuran menentukan karakteristik reologinya selama proses pemanasan. $\mathrm{NaCl}$ meningkatkan ikatan hidrogen dalam pembentukan jaringan gluten selama hidrasi, yang dapat menyebabkan peningkatan $G$ ' yang tinggi pada suhu yang lebih tinggi selama pemanasan. Penundaan peningkatan nilai G' pada suhu yang lebih tinggi selama pemanasan sebagai akibat dari pembentukan jaringan gluten dengan $\mathrm{NaCl}$ bukan karena residu pati dalam jaringan gluten.

Kata kunci: garam, gluten, pati, reologi deformasi kecil, temperature sweep

\section{INTRODUCTION}

Wheat flour contains two forms of proteins, gliadins and glutenins, that contribute and strongly influence the end-product functionality of wheatbased foods. When wheat flour is mixed with water, the gliadin and glutenin proteins are hydrated leading to the formation of a continuous network known as gluten. This network forms the structure of the dough and makes it elastic and extensible. The rheological properties of the gluten protein network, their impact on handling properties of the dough during processing and the resultant end-product quality, depend on a number of factors. These include the quantity and quality of the gluten proteins, their structure at the molecular level, conformational re-arrangements effected by the solvent environment upon hydration as well as physical strain induced by mechanical shear as mixing proceeds (Delcour et al., 2012).

Salt determines the functional rheological properties of the gluten network formed when flour is mixed with water, which in turn affects the 
dough strength and dough-handling properties (Butow et al., 2002). Several studies have been conducted to study the effect of salt on the rheological properties of wheat flour dough and breadmaking quality. Most of the results have proposed that the resulting rheological properties of the dough as influenced by salts are due to the effect of salt on the gluten proteins both indirectly through their effect on water structure and directly upon gluten protein molecules. These effects are primarily dependent on the type of the salts belonging to the Hofmeister series as well as the concentration of the salts (Balla et al., 1998; Butow et al., 2002; Charlton et al., 2007; He et al., 1992; Kinsella and Hale, 1984; Miller and Hoseney, 2008; Preston, 1989).

Our previous study on the effect of sodium chloride on the gluten structure and rheology has shown that the presence of $\mathrm{NaCl}$ in comparison with the absence of $\mathrm{NaCl}$ during dough mixing has increased the non-covalent interaction which resulted in different molecular conformation and network structure of gluten proteins and contributed to the differences in the rheological properties. In addition, the formation of the gluten structure as a function of $\mathrm{NaCl}$ is governed during initial hydration of the flour (Tuhumury et al., 2014). Therefore, the formation of the gluten network during hydration and mixing as function of salt will also determine the behaviour during processing including the baking stage. One particularly important process in breadmaking is the heat denaturation of wheat gluten proteins and the accompanying rheological and functional changes (Schofield et al., 1983). Heating the wet gluten usually increases the molecular size of the glutenin aggregates and decreases protein extractability indicating increased crosslinking and polymerisation of the gluten polymer, which was attributed to increased sulfhydryl-disulfide interchange reactions (Kieffer et al., 2007; Schofield et al., 1983; Stathopoulos et al., 2008; Stathopoulos et al., 2006). Changes occurring during heating have been found to be similar based on the results of most of the rheological studies. Some studies have suggested that rheological properties of gluten during heating with steady decrease of $\mathrm{G}^{\prime}$ and $\mathrm{G}^{\prime}$ ' up to $55^{\circ} \mathrm{C}$, prior to a sharp increase beyond $55{ }^{\circ} \mathrm{C}$, resembling the changes that occur in the parent dough (Lefebvre et al., 1994).

This study has been conducted to investigate the effect of $\mathrm{NaCl}$ on the rheological properties of the gluten during heating. The hypothesis has been that the gluten network formed with $\mathrm{NaCl}$ during hydration determines the rheological properties during heating.

\section{MATERIALS AND METHODS}

\section{Wheat Flour Samples}

Two commercial wheat flours (FSB and Redbase) were kindly provided by Allied Mills (Kensington, Victoria, Australia). The protein contents of the flours were 13.2 and $10.4 \%$ for FSB and Redbase, respectively, determined by the AACC method 46-30 (AACC International, 2000). The moisture contents were 12.8 and $12.9 \%$ for FSB and Redbase, respectively, measured by AACC method 44-15a (AACC International, 2000). A commercial wheat starch was used in trying to confirm the effect of the residual starch. Chemicals used were of analytical grade and $\mathrm{NaCl}$ was purchased from Chem-Supply (Sydney, Australia).

\section{Gluten Washing}

Preparation of water-washed gluten (WW) and salt-washed gluten (SW) was carried out according to the method previously described by Day et al.(2009). Briefly, flour (300 g) was mixed with water $(180 \mathrm{~mL})$ with or without $2 \% \mathrm{NaCl}$ (flour base) in a Hobart mixer at setting 1 (63 rpm) for $2 \mathrm{~min}$ followed by setting $2(111 \mathrm{rpm})$ for a further $2.5 \mathrm{~min}$ to form a dough. The dough was then rested for $30 \mathrm{~min}$ in either water or $2 \% \mathrm{NaCl}$ solution, then washed 3 times by hand in $5 \mathrm{~L}$ water or salt solution $(150 \mathrm{~g} / 5 \mathrm{~L})$. The wet gluten was then freeze-dried for 72-96 h. The freeze-dried gluten was ground to a powder using a coffee grinder and sieved through a $250 \mu \mathrm{m}$ sieve. The gluten samples were prepared in two batches for each flour. Freeze dried gluten $(0.5 \mathrm{~g})$ was rehydrated with $0.75 \mathrm{~mL}$ water or salt solution using a mortar and spatula to obtain a rehydrated gluten dough containing approximately $63 \% \mathrm{w} / \mathrm{w}$ water content for the rheological temperature sweep.

Fresh wet gluten samples were also obtained by mixing flour $(4 \mathrm{~g})$ with $2.4 \mathrm{~mL}$ water or $2 \%$ salt solution for $4.5 \mathrm{~min}$, using a Micro-doughLAB 
(Perten Instruments, NSW, Australia). The gluten sample was then washed in either water for WW gluten or salt solution for SW gluten. A proportion of the fresh wet gluten (approx. $1.5 \mathrm{~g}$ ) was used for the rheological measurement

\section{Reconstitution Studies to Confirm the Effect of Residual Starch}

In order to confirm the effect of salt during heating on gluten itself, the starch was added back to the gluten with increasing concentration to decrease the amount of gluten. The amount of water used is based on the amount of gluten. 10\% decrease in gluten weight equals to $15 \%$ decrease in the amount of water. The gluten starch blend was prepared so the samples contain both WW gluten and SW gluten in $100 \%$ gluten $+0 \%$ starch, $20 \%$ gluten $+80 \%$ starch, and $100 \%$ starch of the total solid. The preparation of the samples was summarised in Table 1.

Table 1. Preparation of the gluten starch blend ${ }^{\mathrm{a}}$

\begin{tabular}{lccc}
\hline Gluten $(\mathrm{g})$ & Starch $(\mathrm{g})$ & $\begin{array}{c}\text { Water } \\
(\mathrm{mL})\end{array}$ & $\begin{array}{c}\text { Water: } \\
\text { total solid }\end{array}$ \\
\hline 0.5 & 0 & 0.75 & 1.5 \\
$0.1(20 \%)$ & $0.4(80 \%)$ & 0.41 & 0.6 \\
0 & 0.5 & 0.8 & 0.4 \\
\hline
\end{tabular}

${ }^{a}$ The amounts of the gluten and starch are the percentage of total solids.

\section{Dynamic Rheological Measurement (Temperature Sweep)}

Temperature sweep was conducted on gluten samples, rehydrated and fresh wet gluten sample as well as the gluten starch blend. The gluten dough and gluten starch dough was then wrapped in plastic film and allowed to rest for $1 \mathrm{hr}$. Dynamic oscillation measurements were performed on a controlled stress-strain rheometer (Paar Physica MCR 300, Messtechnik GmbH, Stuttgart, Germany), using parallel-plate geometry. Top (25 $\mathrm{mm}$ ) and bottom plates were both serrated to prevent the sample from slipping during measurement. The gluten dough was placed between the plates and the upper plate was lowered to a fixed gap of $2 \mathrm{~mm}$ and allowed to rest for 10 min following loading. A purpose-built compartment with a water-saturated filter paper was used to minimise dehydration of the gluten sample during measurement (Day et al., 2009). Oscillation measurements were performed at $1 \%$ strain values, and constant frequency of $1 \mathrm{~Hz}$ (in Linear Viscoelastic Region). For the temperature sweep, samples were heated in the rheometer cell from 25 to $95{ }^{\circ} \mathrm{C}$ at heating rate $1{ }^{\circ} \mathrm{C}$ per minute. Measurements were carried out in duplicate for each gluten preparation.

\section{RESULT AND DISCUSSION}

\section{Effects of $\mathrm{NaCl}$ on the Rheological Properties of Gluten During Heating}

Gluten samples prepared with and without $\mathrm{NaCl}$ during mixing and washing of the dough were subjected to temperature sweep. The rheological profile of the rehydrated gluten samples of the two flours during heating can be seen in Figure 1. Gluten samples from both flours either the rehydrated or the freshly prepared showed a small decrease in both G' and G' up to certain temperature where appeared to be a sharp increase in the G' and G" values. The temperature where the sharp increase in values occurr seems to be determined by gluten network formed during hydration as function of $\mathrm{NaCl}$. The gluten network formed with $\mathrm{NaCl}$ have caused the G' and G', values to be sharply increased at higher temperature (above $60^{\circ} \mathrm{C}$ ) compared to the gluten network formed without $\mathrm{NaCl}$ (around $55{ }^{\circ} \mathrm{C}$ ). After the slump increase, the G' and G" values seemed to be levelled off above the temperature of $85{ }^{\circ} \mathrm{C}$ with the gluten prepared with $\mathrm{NaCl}$ having lower values compared to gluten without $\mathrm{NaCl}$. These results indicated the function of $\mathrm{NaCl}$ in the formation of the gluten network during hydration determine further changes in the structure of the gluten during heating.

Most rheological studies on dough and gluten without $\mathrm{NaCl}$ have found similar changes upon heating and have also showed that effect of heating on dough was the result of what happen to gluten during heating (Lefebvre et al., 1994). It is the steady decrease in $\mathrm{G}^{\prime}$ and $\mathrm{G}$ ' up to $55^{\circ} \mathrm{C}$, followed by a steep increase following this particular temperature, which also in agreement with these current results. The steep increase shifted to higher temperature when the gluten was prepared in the presence of the $\mathrm{NaCl}$ during hydration. Our previous study on the effect of $\mathrm{NaCl}$ on the gluten structure and rheology has shown that $\mathrm{NaCl}$ increased the non-covalent 
interactions of the gluten and the $\beta$-sheet structure which results in different molecular conformation, fibrous network structure, hence differences in rheological properties. $\mathrm{NaCl}$ caused the enhanced hydrogen bondings between the glutenins and aggregation of the gliadins to glutenins (Tuhumury et al., 2014). These increased hydrogen bonding and aggregation of gliadins to glutenins may be the reason for the shifting in the steep increase of the $G^{\prime}$ and G' values to higher temperature. Some studies have also suggested that changes in the gluten structure in the heating process were due to the broken hydrogen bondings (Wang et al., 2001), as the results the structure of the protein opening up cause a gradual decrease in G' and G' "values. Because $\mathrm{NaCl}$ caused the enhanced hydrogen bondings in the formation of the gluten network during hydration, the higher temperature during heating was therefore encountered to break the enhanced bonding compared to gluten without $\mathrm{NaCl}$.
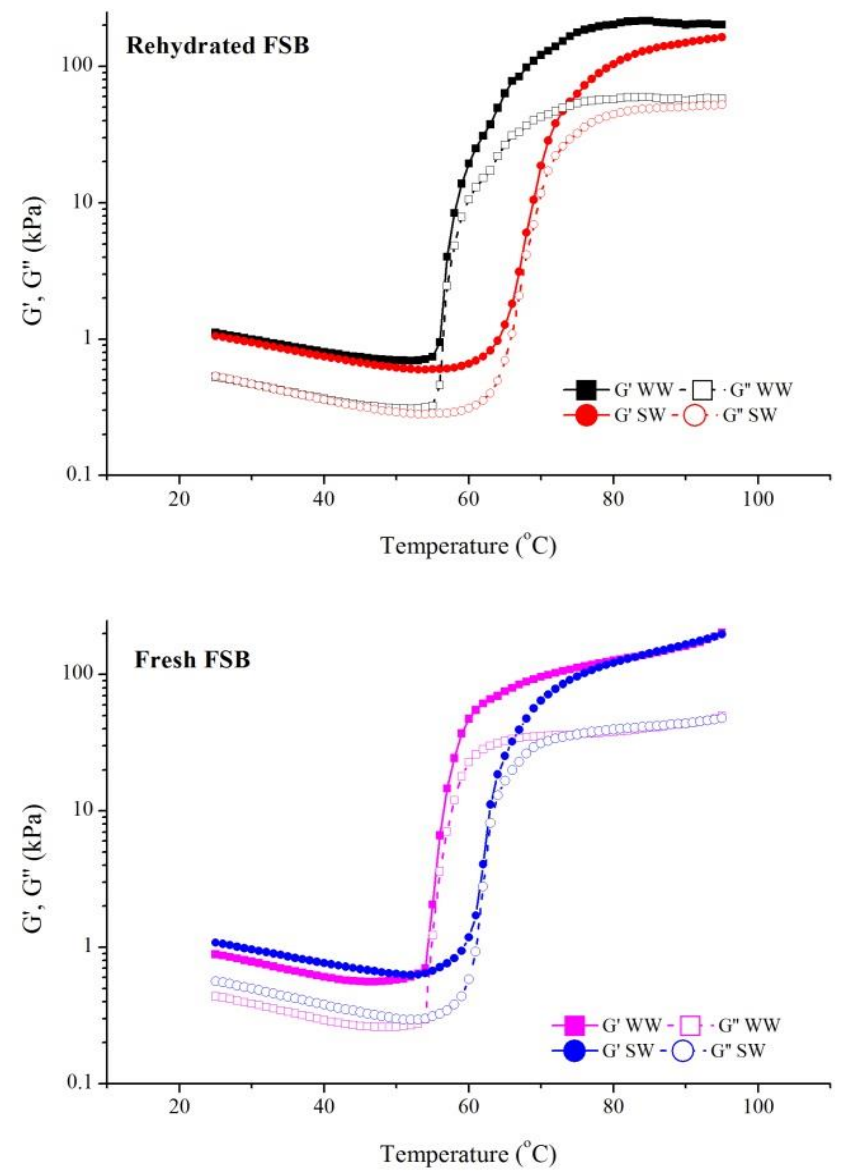

Other studies have shown that with increasing temperature, gluten protein extractability decreased which indicated the heatinduced aggregation of gluten proteins (Stathopoulos et al., 2008). Singh and MacRitchie (2004) also showed that upon heating at higher temperatures, gliadins become more polymerised into glutenins thorough sufhydryl interchanges as it resulted in the decrease in gliadin peak with corresponding increase in the glutenin peak. Therefore, the increase of the G' and G' values at higher temperature may also due the enhanced aggregation of gliadins to glutenins in the presence of $\mathrm{NaCl}$ during gluten network formation.

However, some studies have also found out that there are two processes which are responsible for the thermal behaviour of the dough: starch gelatinisation and protein denaturation. The starch granules which is initially entrapped as filler in the gluten network, may escape the gluten network as it is heated and cause the decrease in the moduli (Salvador et al., 2006).
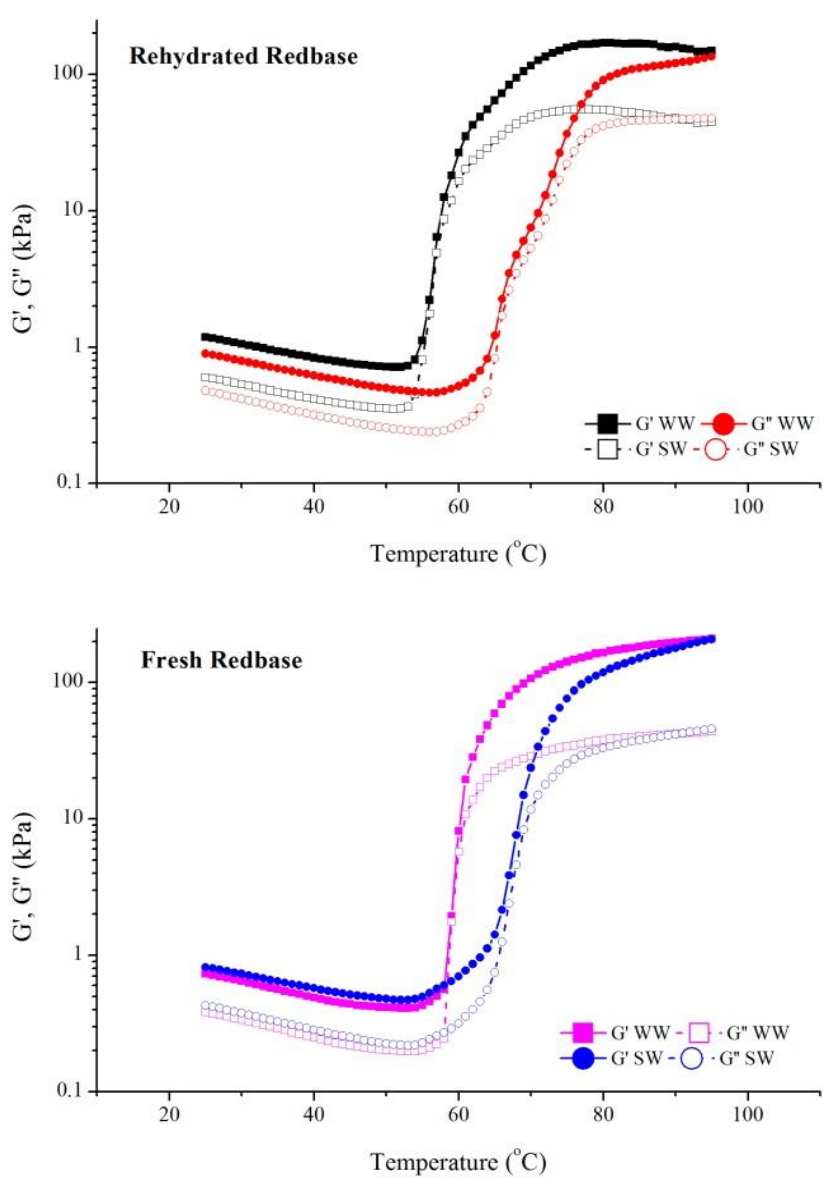

Figure 1. G' and G" values of the rehydrated and freshly prepared water-washed (WW) and salt-washed (SW) gluten from two flours 
Since the gluten network may contain residual starch, the effect of the residual starch has to be taken into account. The next section is designed to investigate the effect of the added starch into the gluten samples prepared with and without $\mathrm{NaCl}$.

\section{Effects of added starch on gluten prepared with and without $\mathrm{NaCl}$ during heating.}

In order to confirm the effect of salt during heating on gluten itself, the starch was added back to the gluten with increasing concentration to decrease the amount of gluten. Figure 2 shows the G' values of the WW and SW gluten with $0 \%$ starch, 20\% starch, and the G' values of the $100 \%$ wheat starch. Upon the addition of starch to the WW and SW gluten samples in the amount of $80 \%$, the starting G' values during heating were higher than $100 \% \mathrm{WW}$ and SW gluten. The gluten samples from different flour with and without $\mathrm{NaCl}$ showed different response of $\mathrm{G}$ ' when starch was added. However, the similar rheological profile were encountered, i.e. a small decrease in both G' and G' ' up to certain temperature where there appeared to be a sharp increase in those particular values.

The gradual decrease of G' during initial heating has been thought to be resulted from the escape of the starch granules which initially entrapped as filler in the gluten network (Salvador et al., 2006). If the gradual decrease in G' value is the result of the starch escaping the gluten network, then the increasing amount of starch in the samples should have shown the sharp decrease in the G' values to certain temperatures.

It can be seen from these results that the similarity in gradual decrease of $G^{\prime}$ values is still observable during initial heating. These results confirmed that the changes in G' during initial heating is determined by the gluten structure. The presence of $\mathrm{NaCl}$ during mixing has also determined how the gluten structure was formed and thus resulted in these specific rheological properties during heating. The results are in agreement with the suggestion that changes in the gluten structure in the heating process were due to the broken hydrogen bondings (Wang et al., 2001). Therefore, the opening of the structure of the protein may cause a gradual decrease in $\mathrm{G}^{\prime}$ and $\mathrm{G}^{\prime}$, values. On the contrary, the amount of starch in the blend proportionally influences the starting point of $G^{\prime}$ values of the samples during heating. The temperature characteristic showed that the less is the amount of gluten, the temperature for the onset of the sharp increase in G' of the gluten with and without $\mathrm{NaCl}$ became more similar with decreasing amount of gluten. On the contrary, the $100 \%$ gluten with and without $\mathrm{NaCl}$ showed that the sharp increase in $G^{\prime}$ values occurred at higher temperature when gluten is prepared with $\mathrm{NaCl}$. If the delay in sharp increase of the $G$ ' values occurred at higher temperature as the results of the presence of residual starch in the gluten network, the samples with higher starch content should also delay this increase to be occurred at higher temperature, however this is not what it looked like in the rheological properties above. These results suggested that the delay of the sharp increase in the $G$ ' to higher temperature during heating is the results of the formation of the gluten network in the presence of $\mathrm{NaCl}$ not of the presence of the residual starch in the gluten network. Therefore, $\mathrm{NaCl}$ which caused the enhanced hydrogen bondings in the formation of the gluten network during hydration, caused the onset in the sharp increase in $G^{\prime}$ at higher temperature during heating. It is because higher temperature was necessary to break the enhanced bonding compared to gluten without $\mathrm{NaCl}$.

\section{CONCLUSION}

Gluten network formed in the presence of $\mathrm{NaCl}$ determine its rheological properties during heating. Changes in the gradual decrease in $G^{\prime}$ and $G$ ' ' values up to certain temperature and the onset of the sharp increase in those values during heating are the results of the amount of the hydrogen bond formation as a function of $\mathrm{NaCl}$. This salt caused enhanced hydrogen bonding in the formation of the gluten network during hydration, which cause the onset in the sharp increase in $G^{\prime}$ at higher temperature during heating. The delay of the sharp increase in the $G$ ' to higher temperature during heating is the result of the formation of the gluten network in the presence of $\mathrm{NaCl}$ not of the presence of the residual starch in the gluten network. 


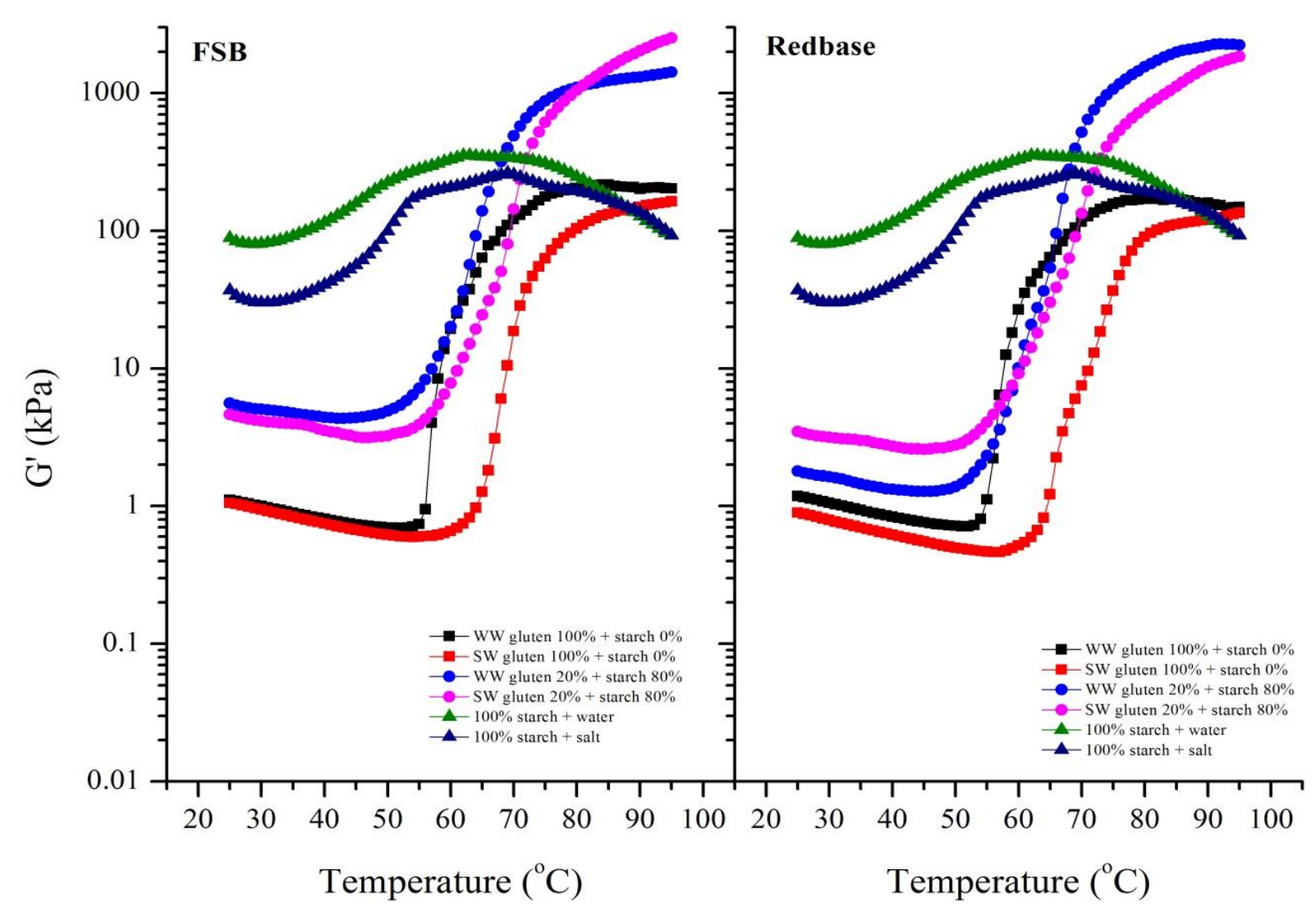

Figure 2. G' values of the rehydrated water-washed (WW) and salt-washed (SW) gluten

\section{REFERENCES}

AACC International. 2000. Approved methods of the AACC (tenth ed.). St. Paul, Minnesota.

Balla, A., H. Razafindralambo, C. Blecker, and M. Paquot. 1998. Interfacial Properties of Gluten Monolayers Spread on Various Chloride Salt Solutions. Effects of Electrolytes, Salt Concentrations, and Temperature. Journal of Agricultural and Food Chemistry 46: 3535-3539. DOI: $10.1021 / \mathrm{jf} 971006 \mathrm{j}$

Butow, B.J., P.W. Gras, R. Haraszi, and F. Bekes. 2002. Effects of different salts on mixing and extension parameters on a diverse group of wheat cultivars using 2-g mixograph and extensigraph methods. Cereal Chemistry 79: 826-833.

DOI: 10.1094/CCHEM.2002.79.6.826

Charlton, K.E., E. MacGregor, N.H. Vorster, N.S Levitt, and K. Steyn. 2007. Partial replacement of $\mathrm{NaCl}$ can be achieved with potassium, magnesium and calcium salts in brown bread. International Journal of Food Sciences and Nutrition 58: 508-521. DOI:10.1080/09637480701331148.

Day, L., M. Augustin, R.J. Pearce, I.L. Batey, and C.W. Wrigley. 2009. Enhancement of gluten quality combined with reduced lipid content through a new salt-washing process. Journal of Food Engineering 95: 365-372. DOI: 10.1016/j.jfoodeng.2009.05.018

Delcour, J.A., I.J. Joye, B. Pareyt, E. Wilderjans, K. Brijs, and B. Lagrain. 2012. Wheat gluten functionality as quality determinant in cereal-based food products. The Annual Review of Food Science and Technology 3: 469-492. DOI: 10.1146/annurev-food022811-101303

He, H., R.R. Roach, and R.C. Hoseney. 1992. Effect of nonchoatropic salts on flour breadmaking properties. Cereal Chemistry 69: 366-371.

Kieffer, R., F. Schurer, P. Köhler, and H. Wieser. 2007. Effect of hydrostatic pressure and temperature on the chemical and functional 
properties of wheat gluten: Studies on gluten, gliadin and glutenin. Journal of Cereal Science 45: 285-292. DOI: 10.1016/j.jcs.2006.09.008.

Kinsella, J.E. and M.L. Hale. 1984. Hydrophobic associations and gluten consistency: Effects of specific anions. Journal of Agricultural and Food Chemistry 32: 1054-1056. DOI: 10.1021/jf00125a027

Lefebvre, J., Y. Popineau, and M. Cornec. 1994. Viscoelastic properties of gluten proteins: Influence of prolamin composition and of temperature gluten proteins. pp. 180-189. Association of Cereal Research, Detmold.

Miller, R.A. and R.C. Hoseney. 2008. Role of salt in baking. Cereal Foods World 53: 4-6. DOI:10.1094/CFW-53-1-0004.

Preston, K.R. 1989. Effects of neutral salts of the lyotropic series on the physical dough properties of a Canadian red spring wheat flour. Cereal Chemistry 66: 144-148.

Salvador, A., T. Sanz, and S.M. Fiszman. 2006. Dynamic rheological characteristics of wheat flour-water doughs. Effect of adding $\mathrm{NaCl}$, sucrose and yeast. Food Hydrocolloids 20: 780-786. DOI: 10.1016/j.foodhyd.2005.07.009.

Schofield, J.D., R.C. Bottomley, M.F. Timms, and M.R. Booth. 1983. The effect of heat on wheat gluten and the involvement of sulphydryl-disulphide interchange reactions.
Journal of Cereal Science 1: 241-253. DOI: 10.1016/S0733-5210(83)80012-5.

Singh, H. and F. MacRitchie. 2004. Changes in proteins induced by heating gluten dispersions at high temperature. Journal of Cereal Science 39: 297-301. DOI: 10.1016/j.jcs.2003.11.004

Stathopoulos, C.E., A.A. Tsiami., J.D. Schofield, and B.J. Dobraszczyk. 2008. Effect of heat on rheology, surface hydrophobicity and molecular weight distribution of glutens extracted from flours with different breadmaking quality. Journal of Cereal Science 47: 134-143. DOI: 10.1016/j.jcs.2007. 03.002 .

Stathopoulos, C.E., A.A. Tsiami, B.J. Dobraszczyk, and J.D. Schofield. 2006. Effect of heat on rheology of gluten fractions from flours with different bread-making quality. Journal of Cereal Science 43: 322-330. DOI: 10.1016/j.jcs.2005.12.004

Tuhumury, H.C.D., D.M. Small, and L. Day. 2014. The effect of sodium chloride on gluten network formation and rheology. Journal of Cereal Science 60(1): 229-237. DOI:10.1016/j.jcs.2014.03.004

Wang, Y., P.S. Belton, H. Bridon, E. Garanger, N. Wellner, M.L. Parker, A. Grant, P. Feillet, and T.R. Noel. 2001. Physicochemical Studies of Caroubin: A Gluten-like Protein. Journal of Agricultural and Food Chemistry 49: 3414-3419. DOI: 10.1021/jf010076u. 